\title{
A Baseline Information Literacy Assessment of Biology Students
}

The University of Maryland, Baltimore County Information Literacy Task Force developed a survey primarily based on the Association of College and Research Libraries Information Literacy Standards to gather baseline data about the skills of incoming students. Although multiple departments were involved, the biological sciences provided the highest number (151) of initial participants for the 51-item online survey. Findings indicate that the majority of students have some understanding of information literacy skills; however, a significant number were not familiar with important concepts such as search techniques, identifying print citations, how to determine bias or quality of sources, and correct citation behaviors when using research or copyrighted works. These data are being used to further develop an information literacy program that focuses on faculty development and targets areas where students lack the necessary skills for academic success and lifelong learning

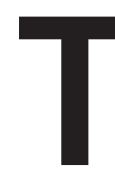

he University of Maryland, Baltimore County (UMBC) Information Literacy Survey is based on the Association of College and Research Libraries (ACRL) Information Literacy Competency Standards for Higher Education (the Standards) and offers a model for future studies of this type. ${ }^{1}$ The results of this survey can provide some interesting insight into the information literacy abilities and attitudes of incoming undergraduates in the biological sciences.

$\mathrm{UMBC}$ is an honors university located in the Baltimore-Washington D.C. corridor. A member of the University System of Maryland, UMBC has programmatic emphases in selected areas of sciences and engineering, mathematics, information and computer science, social sciences (particularly public policy studies), and the arts and humanities. UMBC is a diverse, medium-sized campus, with an undergraduate and graduate enrollment of approximately twelve thousand students. The administration and faculty endorse a philosophy that emphasizes an institutionwide commitment to student-centered learning.

In fall 2001, the UMBC Information Literacy Task Force was formed in the Albin O. Kuhn Library \& Gallery to address the need for a stronger approach to information literacy for the campus. ${ }^{2}$ Although there was a bibliographic instruction program, including a three-credit elective course taught once a year entitled Methods and Materials of Research, little effort had been made to assess the information literacy skills of the student body or to increase awareness of the issues across the campus. The task force decided to investigate exactly how well the students fared with all as-

\section{Jessame E. Ferguson, Teresa Y. Neely, and Kathryn Sullivan}

Jessame E. Ferguson is Head of Public Services, University of Maryland, Baltimore County; Teresa Y. Neely is Director, Zimmerman Library, University of New Mexico, Albuquerque; and Kathryn Sullivan is Reference and Instruction Librarian, University of Maryland, Baltimore County. Submitted November 1, 2004; revised and accepted for publication April 29, 2005.

Reference \& User Services Quarterly, vol. 46 , no. 2 , pp. 61-71

(c) 2006 American Library Association. All rights reserved.

Permission granted to reproduce for nonprofit, educational use. 


\section{FEATURE}

pects of the Standards, and endeavored to develop questions to assess as many performance indicators as possible.

In this article, a literature review looks at similar studies that specifically used the Standards to assess information literacy skills of college students. There is a description of the general method used for the study, select results of the survey arranged by the Standards, a summary of the results, and finally, the future directions to be taken to further develop information literacy skills and awareness on the UMBC campus.

\section{LITERATURE REVIEW}

There is evidence, published and unpublished, of information literacy survey assessment efforts prior to and since the adoption of the ACRL Standards in 2000. Overall, the majority of these efforts have not been based on the Standards. ${ }^{3}$ Consequently, a body of empirical research based on the Standards is almost nonexistent. A recent review of more than seventy information literacy and library research skills-based survey instruments, identified primarily via the Web, revealed that very few were developed based on the Standards. ${ }^{4}$ A review of the literature since 2000 shows some use of the Standards in evaluating the information literacy skills of students and for information literacy program development. ${ }^{5}$

At the ACRL 10th National Conference in Denver, Colorado, GratchLindauer presented selected case studies that used the Standards. ${ }^{6}$ Of the thirteen cases reported, one was a dissertation that used only Standard II and one described the state of Washington's Information Literacy Assessment Group. ${ }^{7}$ The others were institutionally based programs that did not generate research or survey instruments.

Researchers taking part in the Project for the Standardized Assessment of Information Literacy Skills (SAILS) at Kent State University have developed their own set of information literacy standards that resembles a mix of the Standards and the earlier American As- sociation of School Librarians (AASL) standards. ${ }^{8}$ This project is an attempt to develop an instrument that is standardized, easily administered, and can be used to test information literacy skills_thus providing data on a national level. As of June 2004, Project SAILS had 126 items developed, tested, and in use, and most of the outcomes from the Standards have been covered. Similarly, the Bay Area Community Colleges Information Competency Assessment Project, a collaborative project among faculty librarians in the San Francisco Bay Area, has developed and field-tested an information competency assessment instrument that is based on specific performance outcomes, and is criterion referenced to national standards. The Bay Area Project's purpose was to develop a challenge-out or credit-by-exam instrument that can be used at community colleges that have an information competency requirement. An executive summary that details the development and field testing of the instrument was made available in September 2003. ${ }^{9}$

In 2003, Mark and Boruff-Jones demonstrated that librarians can apply results of the National Survey of Student Engagement (NSSE) for the purpose of assessment. ${ }^{10}$ The authors assert that NSSE provides a useful but underused tool for measuring the degree to which information literacy is incorporated into the curriculum at a particular campus. Brown and Krumholz used the Standards as a guide in designing a survey and checklists to measure information literacy levels of students in an upper-level biology course. ${ }^{11}$ A preinstruction survey was given, followed by two instruction sessions. The survey was again administered at the end of the session and revealed a slight increase in some, but not all, of the information literacy skills addressed by the authors. In 2003, Costantino developed and conducted a survey based on Standard II, which deals specifically with search methods and information retrieval systems. The purpose of her study was to investigate whether the academic community perceived information literacy skills as important and whether these skills were being learned. Participants overwhelmingly agreed that information literacy skills are important, but faculty assumed students were learning these skills elsewhere, while students reported not knowing the skills or having been self-taught. ${ }^{12}$ In 2001, Seamans used the Standards to develop interview questions to ask students about their use of information at Virginia Polytechnic Institute and State University for her dissertation. ${ }^{13}$

These findings show that there have been only a few attempts at developing an instrument based exclusively on the Standards to test the information literacy skills of college students. The UMBC Survey provides a model for future information literacy assessment using the Standards.

\section{GENERAL METHOD}

To determine baseline information literacy levels of incoming UMBC students (freshmen and transfer), the task force identified those academic departments with a history of working with the library as targets for the survey. In fall 2003, the survey was made available to five academic departments on the UMBC campus: biology, computer science and engineering, English, history, and psychology. Freshmen and transfer students enrolled in required, core and other courses were identified as the target population. A total of 427 individual students from the targeted courses logged in to take the survey, but only 424 began the survey and answered any questions. One hundred and fifty-one students who began the survey identified themselves as biology students. This group represented the largest number of students from a single department participating in the survey, likely the result of professors in the biology department who awarded extra credit to students who took the survey. The survey was automated using a Web interface and a Microsoft Access database was constructed to facilitate data collection and analysis. 


\section{RESEARCH QUESTIONS}

In addition to specific outcomes within the Standards, the task force investigated a number of research questions, several of which fall within a particular standard. Select survey results and relevant findings will be discussed elsewhere in this article. Detailed findings and a discussion of research questions for the entire population can be found in the UMBC Information Literacy Survey-2003-Executive Summary. ${ }^{14}$

1. What are the attitudes of collegelevel students about Christina Doyle's information literacy skills? ${ }^{15}$

2. Do students who self-report a high level of confidence with information literacy skills perform well when responding to questions that represent those skills?

3. To what extent do students tend to overestimate their information literacy ability levels?

4. To what extent are students able to identify the basic elements of a bibliographic citation?

5. To what extent are students aware of what constitutes plagiarism?

6. To what extent are students familiar with the concept of fair use?

7. To what extent are students familiar with the concept of copyright?

8. Do students who self-report a high level of confidence with computers perform well when responding to questions that represent information literacy skills?

9. To what extent do faculty encourage students to use the library?

\section{INSTRUMENTATION}

With the input of a representative group of faculty and other campus leaders, the Task Force developed a fifty-one item survey based on the Standards. The majority of the questions for the resulting survey were adapted from the Neely Test of Relevance, Evaluation, and Information Literacy Attitudes. ${ }^{16}$ Many of the questions had no right or wrong answers. Most were designed primarily to solicit student perceptions about information literacy skills and the use of information. The sections that make up the UMBC Survey are:

- Standard I-The information literate student determines the nature and extent of the information needed. The survey included questions about resource types and asked students to select those with which they were familiar. For example, one question contained a list of sources including some commonly used materials, such as magazine and journal articles, and some less commonly used, such as conference proceedings, dissertations, and manuscripts.

- Standard II-The information literate student accesses needed information effectively and efficiently. Questions in the survey investigated students' ability to select appropriate resource tools, develop successful search strategies, and extract needed information from their results. For example, one survey question asked students to specify how frequently they use search strategies such as Boolean operators, truncation, and proximity operators.

- Standard III-Information literate students evaluate information and its sources critically and incorporate selected information into their knowledge base and value systems. The survey included questions about students' capabilities in evaluating materials and selecting those most appropriate for a specific purpose. For example, one question asked students to specify how they select the best articles in a list of results from an article database.

- Standard IV-The information literate student uses information effectively to accomplish a specific purpose. The survey included questions about students' abilities to synthesize collected information to produce a final product, such as a research paper. For example, a series of questions in the survey asked students to specify whether they have had the opportunity to present their research using various methods such as PowerPoint, visual projects, or personal Web pages.

- Standard V-The information literate student understands many of the economic, legal, and social issues surrounding the use of information and accesses and uses information ethically and legally. Questions in the survey examined students' views and understanding of copyright, plagiarism, and fair use. For example, one question offered specific writing scenarios (such as rewording someone else's information and using it without giving credit to the author) and asked students to indicate whether they consider it plagiarism.

- Relationship with Faculty-A very important element of information literacy involves students' relationships with their instructors. The survey contained a number of questions that investigate student and faculty relationships, including whether students are comfortable asking their instructors for assistance, and whether students have participated in directed research with a faculty member.

- Attitudinal-A number of questions on the survey gather information regarding students' attitudes about doing research and the information literacy skills themselves. Students were asked to indicate their comfort levels in working with various types of resources, and seeking information from a variety of sources, such as the library homepage.

- Demographics-The survey gathered a great deal of demographic data regarding the participants. In addition to such basic demographic information as academic status, undergraduate major, and previous academic experience, the task force was able to obtain additional data from the UMBC student record system via myUMBC, the university's portal, including gender, age, race, ethnic heritage, country of citizenship, and native language. 


\section{FEATURE}

\section{PILOT SURVEY}

A pilot survey was administered in spring 2003 to students $(n=51)$ employed at the UMBC library to test the survey's technological functionality, to troubleshoot problems, test the comprehensibility of the questions, and obtain feedback from college-level students. Pilot results determined that the survey would take approximately thirty-five to forty minutes to complete.

\section{SPECIFIC PROCEDURES}

In July 2003, the UMBC Institutional Review Board approved the survey instrument and study protocol. A request to waive the signed consent form for each participant was also granted. In August 2003, faculty members were contacted via e-mail. They were provided with a letter explaining the need to support the survey effort and asking them to encourage their students to participate. Faculty members also received a consent letter explaining the survey to be shared with students.

The survey was made available on myUMBC for September 2003. Students accessed the survey by logging into myUMBC and were authenticated by submitting their UMBC unique user ID. The researchers did not have access to any data that linked the unique user ID to individual students. No information was gathered that would violate the personal privacy of the students, and no survey data were released with unique identifiers attached.

Use of the portal enabled longitudinal comparison of data for individuals. The researchers were also able to obtain additional demographic information from the UMBC student record system by submitting the list of unique identifiers to the Office of Information Technology (OIT).

Faculty members received an e-mail update on September 15 that included a roster of the unique user IDs of those students who had logged in to take the survey. No survey data were included in this communication, which also reminded faculty members to encourage students to take the survey. This midmonth reminder to faculty significantly increased survey participation. At the end of the survey, faculty members were sent a roster of students from their classes that completed the survey.

\section{SELECTED FINDINGS AND DISCUSSION}

The freely available UMBC Survey is unique in that it is the only one known to be based on all five of the Standards. Only those institutions participating in the grant for Project SAILS have access to that information literacy instrument and resulting data. The Bay Area Project based its Information Competency Proficiency Exam on a combination of the Standards and the ACRL "Objectives for Information Literacy Instruction: A Model Statement for Academic Librarians." ${ }^{17}$ Although the survey instrument is available upon request, the final report did not include assessment data. ${ }^{18}$ There are many information literacy survey instruments. However, because there is no evidence that queries from these instruments were developed based on the Standards, and due to the unavailability of published research data, comparing and generalizing the findings from this study across populations is difficult or impossible in most of the Standard areas discussed further into this article. ${ }^{19}$

Some participants chose not to answer all of the questions in the survey. Each of the findings reported in this paper are based on the number of students who actually responded to an individual question.

\section{Research Questions}

Question 1: What are the attitudes of college-level students about Christina Doyle's information literacy skills?

Students $(n=147)$ responded to a Likert-type scale (very comfortable, comfortable, undecided/neutral, uncomfortable, very uncomfortable) to indicate their attitudes about the skills. Overall, biology students reported positive attitudes toward the information literacy skills. Table 1 shows that very few students reported feeling uncomfortable or very uncomfortable; and responses for very comfortable and undecided/neutral were largely similar for most skills. These findings point to a clear overestimation of self-reported skills. This overestimation is further confirmed when students are assessed on skills that require them to demonstrate their knowledge.

Question 2: To what extent are students able to identify the basic elements of a bibliographic citation?

Most students in biology were able to correctly identify the parts of a bibliographic citation taken from a journal index. However, fifteen students (11 percent) incorrectly chose the part of the citation listing page numbers when asked for the "volume of journal," and two students confused date with page numbers despite the fact that the date listed was "May '91." Ten students (7 percent) chose the journal title when asked for the "title of article."

Question 3: To what extent are students familiar with the concept of copyright?

Biology students at UMBC are generally not familiar with the concept of copyright, with 33 percent $(n=45)$ reporting that they could legally use pictures from the Internet and 21 percent $(n=29)$ reporting they could, without permission, legally use pictures they scanned from a magazine on their Web sites. Nearly 32 percent $(n=44)$ of those responding reported that they could, without permission, legally use the text of the Homeland Security Act on their Web site. In contrast, 35 percent $(n=48)$ reported they could not legally use that text, and 33 percent $(n=46)$ reported they didn't know. It is unclear whether those responding affirmatively understood the concept of "public domain," because it was not specifically defined or mentioned in the survey.

\section{Standard I}

Standard I states that the information literate student can determine the nature and extent of information needed. The UMBC survey contained six questions related to this Standard, all of them attitudinal. One question asked students to specify their level of com- 
Table 1. Attitudes about Information Literacy Skills

\begin{tabular}{|c|c|c|c|c|c|}
\hline & & & PERCENT & & \\
\hline $\begin{array}{l}\text { Please indicate your comfort level } \\
\text { with the listed skills. }\end{array}$ & $\begin{array}{c}\text { Very } \\
\text { Comfortable }\end{array}$ & Comfortable & $\begin{array}{l}\text { Undecided/ } \\
\text { Neutral }\end{array}$ & Uncomfortable & $\begin{array}{c}\text { Very } \\
\text { Uncomfortable }\end{array}$ \\
\hline $\begin{array}{l}\text { Formulates questions based on } \\
\text { information needs }\end{array}$ & 22 & 56 & 17 & 4 & 0.00 \\
\hline $\begin{array}{l}\text { Identifies potential sources of } \\
\text { information }\end{array}$ & 25 & 57 & 14 & 3 & .68 \\
\hline $\begin{array}{l}\text { Develops successful search } \\
\text { strategies }\end{array}$ & 20 & 51 & 22 & 5 & 1.00 \\
\hline $\begin{array}{l}\text { Accesses sources of information, } \\
\text { including computer-based and } \\
\text { other technologies }\end{array}$ & 30 & 49 & 16 & 5 & 0 \\
\hline Evaluates information & 18 & 56 & 22 & 4 & 0 \\
\hline $\begin{array}{l}\text { Organizes information for practical } \\
\text { application }\end{array}$ & 21 & 52 & 21 & 5 & .68 \\
\hline $\begin{array}{l}\text { Integrates new information into an } \\
\text { existing body of knowledge }\end{array}$ & 17 & 50 & 24 & 7 & .68 \\
\hline $\begin{array}{l}\text { Uses information in critical } \\
\text { thinking and problem solving }\end{array}$ & 19 & 48 & 21 & 10 & 1.00 \\
\hline
\end{tabular}

$\mathrm{N}=147$

fort when seeking information from a variety of sources. Overwhelmingly, students responded that they were most comfortable seeking information from a search engine, with almost 90 percent $(n=129)$ selecting very comfortable or comfortable. (The search engine mentioned the most was Google.) Comparatively, only 63 percent $(n=90)$ of the respondents felt very comfortable or comfortable seeking information from a library Web page. Table 2 reports the complete responses to this question.

When asked to indicate at what point in their research they "brainstorm the concept, using the terms in the topic" more than half $(n=71)$ of those responding selected this as their first step in the research process. A little more than 19 percent $(n=27)$ selected "formulate question based on the information needed to begin the research," as their first step, while 48 percent $(n=67)$ selected this as their second step. Although many students indicated they would use "reference material that provides an overview" of the given topic, most did not select this option for the appropriate stage of research (the beginning). Rather, 21 percent $(n=30)$ selected this as their third step, 25 percent $(n=35)$ as their fourth step, and 27 percent $(\mathrm{n}=38)$ as their fifth step. Collectively, only 12 percent $(n=17)$ selected the use of reference materials as the first or second step in their research. (See table 3 for full results.)

Another question developed for this Standard investigated students' understanding of the value of using a variety of resources, in terms of both types and formats (see table 4). The researchers wanted to gather information on types of resources with which the students were familiar or that they would use in addition to the more commonly used journals and books. The results were as expected. For example, only 20 percent $(n=29)$ of the respondents selected dissertations and theses, and only 11 percent $(n=16)$ selected conference proceedings. Conversely, 88 percent
( $n=126)$ selected Web sites, the most of any selection. The results of this question confirmed the researchers' theory that undergraduates underutilize many excellent sources of information, most of which are easily accessible through a library or a library's Web site.

\section{Standard II}

Standard II addresses the selection of appropriate research methods, including investigative retrieval systems (databases and catalogs), the construction and implementation of effective search strategies, and the retrieval of information in a variety of formats using a variety of classification schemes. The UMBC survey contained seven questions for this Standard focusing primarily on the students' knowledge of search strategy techniques, their ability to construct an effective search strategy, and their ability to identify citations.

Two of the skills in table 1 fall within the scope of Standard II: 71 percent 


\section{FEATURE}

Table 2. Comfort with Information Sources

\begin{tabular}{|c|c|c|c|c|c|}
\hline$N=144$ & & & PERCENT & & \\
\hline $\begin{array}{l}\text { How comfortable/confident do you } \\
\text { feel when seeking information from: }\end{array}$ & $\begin{array}{c}\text { Very } \\
\text { Comfortable }\end{array}$ & Comfortable & $\begin{array}{l}\text { Undecided/ } \\
\text { Neutral }\end{array}$ & Uncomfortable & $\begin{array}{c}\text { Very } \\
\text { Uncomfortable }\end{array}$ \\
\hline a. An Internet Search Engine (see note) & 60 & 30 & 6 & 3 & 1 \\
\hline b. A library web page & 24 & 40 & 27.5 & 8 & 1 \\
\hline c. A friend & 33 & 33 & 25 & 8 & 1 \\
\hline $\begin{array}{l}\text { d. A professor or TA (teaching assistant) } \\
\text { or GSA (graduate student assistant) }\end{array}$ & 22.5 & 49 & 20 & 7 & 1 \\
\hline e. A faculty or class web site & 35 & 50 & 12 & 2 & 0 \\
\hline f. The library & 29 & 45 & 17 & 6 & 3 \\
\hline
\end{tabular}

Note: Google was written in by 67 respondents (49.6\%)

( $\mathrm{n}=105)$ of respondents reported that they were very comfortable or comfortable "developing successful search strategies," and 79 percent $(n=116)$ reported that they were very comfortable or comfortable "accessing sources of information, including computer-based technologies." A related question was created to assess how frequently students used search strategies. Although the UMBC survey included examples describing all of the search strategies in this survey question, 66 percent $(n=93)$ of those responding reported that they infrequently use or never use truncation, 66 percent $(n=93)$ reported that they infrequently or never use proximity operators, and nearly 74 percent $(n=103)$ reported that they infrequently or never use "Library of Congress Subject Headings, ERIC descriptors, or some other controlled vocabulary." "Cross and multiple-field searching," and such limiters as date, were occasionally used by fewer than 30 percent $(n=39)$ of those participating. Forty-two percent $(\mathrm{n}=60)$ use "cross and multiplefield searching" frequently or very frequently; however, fewer than 32 percent $(n=45)$ use limiters frequently or very frequently. Significant percentages of "infrequent or never use" responses to other searching techniques included Boolean operator OR-50 percent $(\mathrm{n}=70)$ and Boolean operator NOT—66 percent $(\mathrm{n}=92)$.
Table 3. Early Steps in the Research Process

"Violence in American high schools" is a popular topic because it is a growing problem. Given this topic as the subject of a research project, in what order would you perform these steps? ( 1 = first step; 2 = second step, and so on; use 0 if you would not take a particular step)

\section{PERCENT}

Browse a current $\begin{array}{cccccccc}\mathbf{0} & \mathbf{1} & \mathbf{2} & \mathbf{3} & \mathbf{4} & \mathbf{5} & \mathbf{6} & \mathbf{7} \\ 14 & 7 & 6 & 3.5 & 11 & 12 & 22 & 24\end{array}$

printed magazine index

$\begin{array}{lllllllll}\text { Browse the most recent } & 8.5 & 5 & 6 & 6 & 14 & 26 & 26 & 6\end{array}$
issue of an education journal

Search the Internet

using keywords

"violence" and "high

schools"

Look at reference

$3 \quad 3.5$

material that provides

an overview of violence

and teenagers

Brainstorm the concept, using the terms in the

topic

Formulate questions based on the

information needed to

begin the research

Search subject-based and other related databases
$\mathrm{N}=140$ 
Table 4. Types of Information Used by College Students

\begin{tabular}{|c|c|}
\hline \multicolumn{2}{|c|}{$\begin{array}{l}\text { Other than "books" and "journals," what } \\
\text { other types of information are you } \\
\text { familiar with or might use for a research } \\
\text { project/paper? Please select all that } \\
\text { apply. }\end{array}$} \\
\hline TYPE & PERCENT \\
\hline Web sites & 88 \\
\hline Newspapers & 81 \\
\hline Magazines & 80 \\
\hline Interviews & 53 \\
\hline Images/pictures & 50 \\
\hline Speeches & 50 \\
\hline Videos/movies/DVDs & 48 \\
\hline Television shows/broadcasts & 40 \\
\hline Television/radio transcripts & 31 \\
\hline Diaries/letters & 26 \\
\hline Manuscripts & 26 \\
\hline Music & 26 \\
\hline Radio shows/broadcasts & 23 \\
\hline Dissertations/theses & 20 \\
\hline Conference proceedings & 11 \\
\hline $\begin{array}{l}\text { Other } \\
\text { (Internet, journals, } \\
\text { scholarly journals) }\end{array}$ & 3 \\
\hline None of the Above & 1 \\
\hline
\end{tabular}

In terms of accessing sources of information, a related question provided twelve options and asked students to respond to "Where would you go or what would you do to find current information on the following topic: Terrorism on college campuses?" Students were not asked to rank the order and were able to select as many options as were applicable. Overwhelmingly, nearly 96 percent of biology students ( $n=137)$ selected "Online-Internet" as the place they would go to find current information on this popular topic. Seventy-three percent of students $(n=104)$ selected "newspaper archives," 70 percent $(n=100)$ selected magazines, and 66 percent $(n=94)$ selected "television news." Fewer students would seek information from "friends/colleagues" -
46 percent $(n=66)$, "radio news"-39 percent $(n=56)$, a librarian-38 percent $(n=54)$, "faculty/professors"-34 percent ( $\mathrm{n}=48)$, and "television/radio transcripts" - 29 percent $(n=42)$. Even fewer would consider accessing "abstracts and indexes (databases)_electronic" 22 percent $(n=32)$, encyclopedias -15 percent $(n=21)$, and "abstracts and indexes_print"-14 percent $(n=20)$.

When asked when they would consult a librarian for assistance, 87 percent $(n=125)$ of those participating reported they would when they "need advice about where to look for information," 77 percent $(n=110)$ would when they "don't know how to use an information source," and 68 percent (n=97) would when they "need help choosing the best information source." Fifty-nine percent $(n=84)$ of the students selected "all of the above," and two students responded that they "don't know when you would consult a librarian for assistance."

When given a list of citations and asked to identify what each citation referred to, 43 percent or fewer of those responding to this question correctly identified the two citations for journal articles $(n=61$ and $n=59)$. Fewer than 85 percent correctly identified the citation for a newspaper (83 percent $(n=117)$ ), a government document (74 percent $(n=104))$, and a master's thesis (75 percent $(n=106))$, even though the newspaper citation listed the New York Times, the government document citation included the words "United States Congress" as the author, and the thesis citation listed "master's thesis." Only 55 percent ( $n=78)$ correctly identified the citation for a book, 32 percent $(n=45)$ correctly identified a book chapter, and fewer than 45 percent ( $n=63$ ) correctly identified a citation for a conference proceeding, even though the citation included the word "conference."

\section{Standard III}

Standard III primarily focuses on the student's ability to evaluate information and sources. The UMBC survey contained eleven questions related to this Standard. The majority of the questions written for this Standard were designed to ascertain students' perceptions of the reliability, credibility, and usefulness of sources of information. Additional questions were developed to determine how students evaluate information.

When asked about their level of comfort "evaluating information" (see table 1), fewer than 74 percent $(n=108)$ reported feeling very comfortable or comfortable. However, when asked to rate the usefulness of resources when doing research, on a scale of 1 (least useful) to 5 (most useful) "published in a refereed journal" received a ranking of 5 from only 14 percent $(n=20)$ of those participating $(n=140)$; "theses and dissertations" were ranked 5 by 13 percent $(\mathrm{n}=18)$; and "written by a university faculty" also received a ranking of 5 from 9 percent $(n=13)$ — these last two receiving their rankings from the smallest number of students. "Published in a textbook" received the highest ranking by slightly more than 47 percent $(n=66)$, followed by 36 percent for "available in a research library" $(n=50)$, and 24 percent for "indexed in a computer database" ( $n=33)$.

When asked if one could evaluate an article for bias before reading it, 31 percent $(n=44)$ selected, "No. I need to read an article to find bias"; 15 percent $(n=21)$ incorrectly selected "Yes. The abstract usually evaluates the article and notes any bias"; nearly 21 percent $(n=29)$ incorrectly selected "Yes. If the article is reporting research, it should be unbiased"; and 18 percent $(\mathrm{n}=25)$ selected "I don't know." Fifteen percent $(n=21)$ selected "Yes. The reputation of a journal publisher or author may indicate bias."

To determine which sources college-level students considered credible, the UMBC survey included two questions that asked students when (always, sometimes, never) they would consider the sources credible or reliable for their research. One question included ten items and focused on print media, and another included seventeen items that focused on broadcast and online news media. Similar examples were grouped together to increase recognition of a given type of source. Fifty-eight percent $(\mathrm{n}=81)$ felt that "Time or Newsweek" 


\section{FEATURE}

were always credible; 53 percent $(n=74)$ felt the same way about the "New York Post," and 63 percent (n=88) about the "New York Times/Washington Post/Los Angeles Times/Baltimore Sun." Many of the mainstream journals and publications listed were considered sometimes credible by 40 percent or more of those responding, including "Ebony" 49 percent ( $\mathrm{n}=68)$, "Time or Newsweek" 41 percent ( $\mathrm{n}=58)$, "New York Post" 44 percent ( $\mathrm{n}=62)$, "Rolling Stone/Vibe" 51 percent ( $\mathrm{n}=72)$, "Sports Illustrated" 59 percent ( $\mathrm{n}=82)$, "People" 50 percent $(\mathrm{n}=70)$, and "Entertainment Weekly" 42 percent $(n=59)$. Seventy-one percent $(\mathrm{n}=99)$ never considered the "National Enquirer" credible; 64 percent $(\mathrm{n}=89)$ felt the same way about "Seventeen or Vogue"; and 56 percent $(\mathrm{n}=78)$ about "Entertainment Weekly." "Ebony" was never considered credible by 49 percent $(\mathrm{n}=69)$.

In terms of broadcast and online news media, the majority (70 percent) reported that CNN News/Headline News $(\mathrm{n}=98), 68$ percent that $\mathrm{Cnn} . \mathrm{com} / \mathrm{Head}-$ line news.com $(n=95)$, and 59 percent that World News Tonight/CBS Evening News ( $\mathrm{n}=83$ ) were always credible. Interestingly, little more than 7 percent $(\mathrm{n}=10)$ always considered Black Entertainment Television News/BET Tonight credible; and slightly more than 20 percent $(\mathrm{n}=30)$ reported that they felt the Today Show/Good Morning Americal
The Early Show were always credible. Saturday Night Live's "Weekend Update" was felt to be sometimes credible by 12 percent $(\mathrm{n}=17)$.

Another question listed some sources of information and asked students if they thought they were reliable (always, sometimes, never). Seventy-seven percent $(n=108)$ reported that they would always consider "sources recommended by professors, librarians, and teaching assistants" reliable; and 81 percent ( $n=114$ ) reported they would sometimes consider "sources found on the Internet" reliable. Slightly more than 17 percent $(n=24)$ always considered "sources found on the Internet" reliable.

\section{STANDARD IV}

Key concepts for this Standard are the ability to organize information and the ability to communicate that information effectively and efficiently to accomplish a specific task. The UMBC survey contained seven attitudinal questions regarding this Standard.

In terms of the research process, students responded with the level of frequency with which they complete certain related tasks. Sixty-four percent $(n=89)$ of the respondents indicated that they "revise outline based on research findings" very frequently or frequently. About 23 percent $(n=32)$ indicated they "synthesize major points and concepts under outline headings" very frequently, while 44 percent $(n=62)$ reported doing so frequently. Table 5 contains the complete results of this question; parts $\mathrm{f}$ and $\mathrm{g}$ are relevant to Standard IV.

Another question listed various presentation methods and asked students to indicate which they would be comfortable using. Students could select as many methods as they wished. The method receiving the highest number (84 percent) of positive responses was a "written research paper" ( $n=119)$. "Presentations using PowerPoint or other presentation software" received the second highest response rate with 66 percent $(n=94)$. Methods receiving the lowest responses included: 25 percent for "Web pages/site" ( $\mathrm{n}=35$ ), 23 percent for "VHS" ( $\mathrm{n}=33)$, and 18 percent (n=26) for both "CD" and for "DVD."

\section{STANDARD V}

Standard V focuses primarily on the student's understanding of privacy, security, censorship, copyright, fair use, and plagiarism. The UMBC survey contained six questions related to this Standard. The survey provided a definition of plagiarism and asked students to identify examples of plagiarism from a list of choices. Ninety-six percent ( $n=135)$ of the respondents selected the option "using phrases and sentences of

Table 5. Further Steps in the Research Process

After you have done your initial research for a paper, how often do you do the following?

a. Understand all of the information

b. Discuss findings with friends and colleagues

c. Make an outline

$\mathrm{d}$. Review the original research questions to determine if additional information is needed

e. Discard irrelevant or useless information

f. Revise outline based on research findings

g. Look at materials under each outline heading and synthesize major points and concepts

\section{PERCENT}

$\begin{array}{ccccr}\begin{array}{c}\text { Very } \\ \text { Frequently }\end{array} & \text { Frequently } & \text { Occasionally } & \text { Infrequently } & \text { Never } \\ 26 & 57 & 15 & 1 & 1 \\ 11 & 29 & 46 & 12 & 1 \\ 14 & 36 & 36 & 11 & 2 \\ 35 & 42 & 19 & 3 & 1 \\ 33 & 46 & 17 & 3 & 1 \\ 19 & 45 & 26 & 9 & 14 \\ 23 & 44 & 26 & 4 & 3\end{array}$

$\mathrm{N}=140$ 
others as if they were your own without giving credit (to the author)." However, the number of students who selected "rewording someone else's information and using it without giving credit (to the author)" dropped to 77 percent $(n=109)$. This inability to recognize that you must cite the work of others was also revealed in the results of another question. Students were asked in which instances they would provide a citation when writing a research paper that included article research. When the example involved rewriting article research in their own words, 42 percent $(n=59)$ did not choose this example as one that required citation.

The concepts of copyright and fair use were also defined in the survey. Students were then asked to identify whether or not they could legally use specific examples of works on their own Web page without permission. The option that revealed the highest number (72 percent) of "No" responses $(n=99)$ involved scanning in text from a Harry Potter book. It was good to see that the majority of the students respect copyright laws in print; however, there were thirteen students (9 percent) who did not see this as a violation of copyright, and twenty-six (19 percent) who did not know. When asked about using "the theme song from Titanic by Celine Dion" on their Web page without permission, results show that 21 percent $(n=29)$ believed they could use it, and 22 percent $(n=31)$ responded that they did not know. Though the concept of "public domain" was not defined in the survey, examples of such resources (presidential speeches, acts of Congress) were also included, and the results indicated that most students were not able to identify these as works that can be used without permission.

Students were then asked to identify examples of fair use when preparing an assignment for class. Only 76 percent $(\mathrm{n}=105)$ indicated that quoting from an article without citing a source was not legal, and 12 percent $(n=17)$ indicated they did not know. When students were given the option to use a video clip from the Rosie O'Donnell Show as part of a class presentation on talk shows,
70 percent ( $\mathrm{n}=97$ ) correctly identified that they could legally use this example. Other responses revealed further uncertainty, such as the example of copying a reserve item "your professor" placed in the library. Fifty-five percent $(\mathrm{n}=76)$ only a slight majority—responded "Yes" to this example of fair use.

\section{ADDITIONAL FINDINGS}

Some survey questions the task force included fell outside of those written for the Standards, but provided some important background information about the students' prior experience with libraries. For example, when asked about the importance of learning more about the library, more than 85 percent $(n=121)$ of those responding indicated that it was very important or important. Also surprising were the findings indicating their experiences using libraries. Only 25 percent $(n=35)$ selected "whenever I use the library, I find what I want," and 62 percent $(\mathrm{n}=88)$ reported, "I can usually find what I want, but there are frustrations." Results for another question show fewer than 33 percent $(n=47)$ selected "whenever I use the Internet, I find what I want," and nearly 55 percent $(n=78)$ selected, "I can usually find what I want [on the Internet], but there are frustrations." Nine percent $(n=13)$ each reported, "the Internet is frustrating; I find it difficult to find the information I need" and "I generally avoid the Internet." These findings confirm that students are using the Internet to find information; however, they also confirm that students are not always successful and experience frustration when using both the Internet and libraries.

\section{SUMMARY}

The majority of the students participating in the survey were white freshmen born in the United States, age twenty and under. More than 60 percent graduated from high school in 2003, 21 percent had not declared a major at the time of the survey, and about 20 percent were transfer students. More than half were female. Including the United
States, eight countries were represented. After comparing the survey population with that of the campus overall, it was determined that the respondents to the survey adequately represent the ethnic and racial makeup of the campus.

The findings indicate that biology students will seek information from the Web before they will go to other sources of information (such as the library). Students self-report very high comfort levels seeking information from a search engine; however, they are more comfortable seeking information from the library itself than from the library's homepage.

The data confirm that students overestimate their ability levels with many skills represented in the survey. In particular, students indicated that they were comfortable developing successful search strategies, yet they were unfamiliar with basic search concepts such as Boolean operators, truncation, and controlled vocabulary. A significant number of the respondents had difficulty identifying citations for such sources as journal articles, books, newspaper articles, and book chapters.

Students indicated high levels of comfort with evaluating information. However, when presented with questions that allowed them to rate the usefulness of sources, several key forms of quality research-such as theses, dissertations, and refereed journals-were rated lower than less scholarly resources. Many students could not identify the reputation of the journal or author as a possible indication of bias. More than two-thirds of the respondents reported that they would always consider sources recommended by professors, librarians, and teaching assistants reliable. However, not all students reported feeling comfortable asking professors for research assistance.

The survey included a question about steps taken after gathering research. The majority of students indicated that they review their original research questions, determine if additional resources are needed, and discard irrelevant information. Results show that nearly a quarter of the respondents are not comfortable when synthesizing 


\section{FEATURE}

the information they gather or when integrating new information into an existing body of knowledge. Other results show that students are comfortable presenting their research findings using technological methods, such as PowerPoint, but fewer are comfortable using a Web page.

When presented with questions related to copyright and plagiarism, the majority of responses indicate that students understand basic legal issues surrounding the use of information. However, there are a significant number of students who do not apply basic principles of ethical information use in their role in the academic environment. Overall, students responded correctly to a question about how they used information for a research project, such as directly quoting a source and citing it. But there were a number of students who would use information without giving credit to the author or creator, or who would violate laws by placing copyrighted works on their personal Web sites without asking permission.

\section{FUTURE DIRECTIONS}

This survey was the first of its kind at $\mathrm{UMBC}$, and based on the findings and lessons learned, the task force is confident that this endeavor was successful in many ways. In terms of future assessment efforts, the task force will further refine the survey instrument to decrease the length, add more technological literacy questions, and develop additional questions that require students to demonstrate their abilities. To increase participation in future surveys, the task force envisions garnering institutional support for mandatory participation, increasing the number of academic departments targeted, and determining information literacy levels of graduate students.

The task force has developed a plan to increase awareness of information literacy on campus and to improve the information literacy skills of students at UMBC. The plan will focus on reaching the students through faculty development, and includes the development of brown bags to generate awareness of information literacy on campus and to share survey findings, creation of a slide show based on key findings to be run on the campus' closed-circuit television network, offering of workshops (for example, copyright law, fair use, assignment development), and developing a Web site with resources for integrating information literacy into the curriculum.

\section{References and Notes}

1. Association of College and Research Libraries, Information Literacy Competency Standards for Higher Education (Jan. 2000), www.ala.org/acrl/ilcomstan.html (accessed Feb. 6, 2005); The UMBC survey is available online at: http://aok.lib umbc.edu/reference/informationliteracy/ umbcsurvey.pdf (Aug. 15, 2006). Permission to use or distribute this survey is granted, provided that the following copyright notice appears on the original version: Copyright (C) UMBC 2003, AOK Library \& Gallery, UMBC, 1000 Hilltop Circle, Baltimore, MD 21250

2. UMBC Task Force members: Teresa Y. Neely-Head of Reference (currently, Director, Zimmerman Library, Univ. of New Mexico); Jessame E. FergusonHead of Circulation \& Media; Simmona Simmons-Hodo-Services Development $\&$ Special Projects Librarian; and Kathryn Sullivan-Reference and Instruction Librarian

3. See Lut Rahim Nero, "An Assessment of Information Literacy Among Graduating Teacher Education Majors of Four Pennsylvania State System of Higher Education (SSHE) Universities" (Ph.D. diss., Univ. of Pittsburgh, 1999); Teresa Yvonne Neely, "Aspects of Information Literacy: A Sociological and Psychological Study" (Ph.D. diss., Univ. of Pittsburgh, 2000); Patricia Davitt Maughan, "Assessing Information Literacy Among Undergraduates: A Discussion of the Literature and the University of California-Berkeley Assessment Experience," College \& Research Libraries 62, no. 1 (Jan. 2001): 71-85; Molly R. Flaspohler, "Information Literacy Program Assessment: One Small College takes the Big Plunge," Reference Services Review 31, no. 2 (2003): 129-40-this study used the ACRL Standards to develop interventions. However, the survey instrument was developed at UCLA Libraries based on standards developed in 1998: Patti S. Caravello et al., "UCLA Library Instructional Services Advisory Committee Questionnaire," in Information Competence at
UCLA: Report of a Survey Project (Apr. 1, 2001), 23-29, Univ. of California, Los Angeles, Information Literacy. Paper 01. http://repositories.cdlib.org/uclalib/ il/01 (accessed Aug. 15, 2006); Carol A. Powell and Jane Case-Smith, "Information Literacy Skills of Occupational Therapy Graduates: A Survey of Learning Outcomes," Journal of the Medical Library Association 91, no. 4 (Oct. 2003): 468-78.

4. Teresa Y. Neely, Information Literacy Assessment: Standards-Based Tools and Assignments (Chicago: ALA, 2006).

5. Flaspohler, "Information Literacy Program Assessment"; Maria Grant and Marlowe Berg, "Information Literacy Integration in a Doctoral Program," Behavioral \& Social Sciences Librarian 22, no. 1 (2003): 11528; Kate Manuel, "Science and Information Literacy on the Internet: Using the ACRL and Project 2006 Standards to Create a Science Web Page Evaluation Tool," Issues in Science \& Technology Librarianship no. 30 (Spring 2001), www.istl .org/01-spring/confl.html (accessed Aug. 10, 2006); Lori E. Buchanan, DeAnne L. Luck, and Ted C. Jones, "Integrating Information Literacy into the Virtual University: A Course Model," Library Trends 51, no. 2 (Fall 2002): 144-57; Jeanne R. Davidson, Paula S. McMillen, and Laurel S. Maughan, "Using the ACRL Information Competency Standards for Higher Education to Assess a University Library Instruction Program," Journal of Library Administration 36, no. 1/2 (2002): 97-122.

6. Bonnie Gratch-Lindauer, "Selected Case Studies Using the Information Literacy Competency Standards for Higher Education," compiled for the ACRL 10th National Conference (Denver, Colo., Mar. 15-18, 2001), www.ala.org/ala/ acrl/acrlissues/acrlinfolit/infolitstandards/ using/standardscase.htm (accessed Feb. 6, 2005).

7. Connie E. Costantino, "Stakeholders' Perceptions of the Importance of Information Literacy Competencies within Undergraduate Education" (Ed.D. diss., Alliant International Univ., 2003); The State of Washington developed an assessment instrument for their Information Literacy as a Liberal Art course in 1998, www.washington.edu/oea/pdfs/reports/ 9810q.pdf (accessed Aug.15, 2006).

8. Lisa G. O'Connor, Carolyn J. Radcliff, and Julie A. Gedeon, "Assessing Information Literacy Skills: Developing a Standardized Instrument for Institutional Longitudinal Measurement," in Crossing the Divide: Proceedings of the Tenth National Conference of the Association of College and Research Libraries (Chicago: Association of College and Research Libraries, 2001), 
163-74, www.ala.org/ala/acrl/acrlevents/ oconnor.pdf (accessed Aug. 15, 2006).

9. Bay Area Community Colleges Assessment Project Team, Bay Area Community Colleges Assessment Project: A Two-Part Information Competency Assessment Exam (San Francisco: Bay Area Community Colleges, Oct. 2003), www.topsy.org/ ICAP/ICAProject.html (accessed Oct. 14, 2004). The Bay Area Community Colleges Assessment Project Team includes: Bonnie Gratch-Lindauer, project leader, Pam Baker, Amelie Brown, Micca Gray, Andy Kivel, Brian Lym, and Topsy Smalley.

10. Amy E. Mark and Polly D. Boruff-Jones, "Information Literacy and Student Engagement: What the National Survey of Student Engagement Reveals About Your Campus," College \& Research Libraries 64, no. 6 (Nov. 2003): 480-93.

11. Cecelia Brown and Lee R. Krumholz, "Integrating Information Literacy Into the Science Curriculum," College \& Research Libraries 63, no. 2 (Mar. 2002): 111-23.

12. Costantino, "Stakeholders' Perceptions of the Importance of Information Literacy Competencies."
13. Nancy H. Seamans, "Information Literacy: A Study of Freshman Students' Perceptions, with Recommendations" (Ph.D. diss., Virginia Polytechnic Institute and State Univ., 2001).

14. UMBC Information Literacy Task Force, UMBC Information Literacy Survey2003-Executive Summary (Baltimore, Md.: Albin O. Kuhn Library \& Gallery, Nov. 2003), http://aok.lib.umbc.edu/ reference/informationliteracy/ESinfolit2003.pdf (accessed Aug. 15, 2006).

15. The UMBC Survey was developed based on the Neely Test of Relevance, Evaluation, and Information Literacy Attitudes. The Neely Survey used Christina S. Doyle's information literacy skills because the ACRL Standards had yet to be developed. See Christina S. Doyle, "Development of a Model of Outcome Measures for Information Literacy within the National Education Goals of 1990" (Ph.D. diss., Northern Arizona Univ., 1992); Neely, "Aspects of Information Literacy."

16. Neely, "Aspects of Information Literacy."
17. ACRL, "Objectives for Information Literacy Instruction: A Model Statement for Academic Librarians," 2001, www .ala.org/ala/acrl/acrlstandards/objectivesinformation.htm (accessed Aug. 16, 2006).

18. Bay Area Community Colleges Assessment Project Team, "Final Report of the Bay Area Community Colleges Information Competency Assessment Project," www.topsy.org/ICAP/FinalReport.pdf (accessed Feb. 6, 2005).

19. The UMBC survey was based on the Neely Survey, which surveyed undergraduate and graduate education students. Query development for the UMBC survey added, revised, and deleted queries from the Neely survey. The researchers believe that comparing findings from the two surveys would not be appropriate based on demographics and query changes. 